\title{
IDENTIFYING CUSTOMARY INTERNATIONAL LAW: FIRST THOUGHTS ON THE ILC'S FIRST STEPS
}

\author{
Edward T. Swaine*
}

The International Law Association's Statement of Principles Applicable to the Formation of General Customary International $\mathrm{Law}^{1}$ (2000) was a welcome addition to an admittedly voluminous literature. Stepping into the void of authoritative commentary, it balanced an estimable representation of contemporary thinking while it also tendered sometimes controversial views on unresolved matters. Though nominally on the same subject, the International Law Commission (ILC) project offers different strengths and faces different challenges. As the First Report ${ }^{2}$ by the Special Rapporteur, Sir Michael Wood, has noted, the ILC's relationship with States, in particular, provides it with a special vantage and authority. This vantage may also make its pronouncements less tendentious, and more conservative, in character. I'd like to assess the (very early) returns on how this potential differentiation is faring. For sake of brevity, I will focus mostly on a likely harbinger, the treatment of State practice, as reflected in the Draft Conclusions already adopted by the Drafting Committee ${ }^{3}$ - including parts of the Second Report ${ }^{4}$ bearing upon them. Any stylistic or substantive criticism of the existing work recognizes, of course, that it is at an early stage, and that one of ILC's many virtues is the deliberate and careful evolution of its projects.

One early indicator of conservatism, highlighted by my colleague Sean Murphy, is the ILC's apparent interest in reinforcing the requirement of opinio juris. As compared to the ILA's principles, the Special Rapporteur appears intent on recalling a sense of legal obligation as a true prerequisite for the formation of custom, rather than a typical or desirable but not strictly mandatory feature. This was reinforced in the Drafting Committee, which inserted the term opinio juris as a call-out to the traditional requirement, and by wording changes to the title of Draft Conclusions 2 (Two constituent elements) and 3 (Assessment of evidence for the two elements). As revised, Draft Conclusion 1 (Scope) is now another indicator: the Drafting Committee excluded a potentially confusing proviso that the conclusions were "without prejudice to the methodology of other sources of international law." Perhaps the most consequential, if mixed, signal is Draft Conclusion 4 (Requirement of practice), paragraph 1 of which states that "it is primarily the practice of States" that matters. Although this surely opens the door, paragraph 2 prevents it from swinging too far; it fills the space afforded by paragraph 1 and limits inference that other types of practice, like that of non-State actors such as NGOs,

* Edward T. Swaine is Professor of Law at The George Washington University Law School.

Originally published online 23 Dec. 2014.

${ }^{1}$ Int'l Law Ass'n, London Conference, 2000, Final Rep. of Comm. on Formation of Customary (General) International Law, Statement of Principles Applicable to the Formation of General Customary International Law (2000).

2 Michael Wood, Special Rapporteur, First Rep. on Formation and Evidence of Customary International Law 3, Int'l Law Comm'n, UN Doc. A/CN.4/663 (May 17, 2013).

${ }^{3}$ Gilberto Saboia, Chairman of the Drafting Committee, Statement on the Identification of Customary International Law, Int'l Law Comm'n (Aug. 7, 2014).

${ }^{4}$ Michael Wood, Special Rapporteur, Second Rep. on Identification of Customary International Law, Int'l Law Comm'n, UN Doc. A/CN.4/672 (May 22, 2014).

ASIL and Edward T. Swaine (C) 2014 
matter as well by allowing that "[i]n certain cases, the practice of international organizations also contributes" to practice.

Mitigating these conservative and State-centered gestures, however, is the inevitable impulse to articulate principles expansively and inclusively. Anyone cataloging the circumstances in which customary international law might be found is hesitant to exclude anything, even conditions that generally seem unpromising. One can speculate about why this is. Perhaps the cost of a false negative is objectively more substantial than that of a false positive. Perhaps those of us who consider international law to be a worthy enterprise are likely to hesitate before casting doubt on some aspects of its existence. (Critics of customary international law, on the other hand, might liken this tendency to finding a disease based on a symptom or two- or to over-diagnosis, in which the diagnosis is technically correct but practically irrelevant.) Perhaps over-inclusiveness is driven by insufficient integrity in the core inquiry or by a lack of clarity on the margins of how, exactly, international law is formed. Perhaps the tendency is accentuated when drafting by consensus is required, or when the context is one in which not only scholars and States, but also international organizations, are potential veto players.

What evidence of this expansionary tendency, if any, appears in ILC's efforts to date? The merest hint is provided by the project's evolution from one concerning "Formation and evidence of customary international law" into "Identification of customary international law." This clearer and more modest undertaking suggests less insistence on relating the forensic task of identification to the foundational task of justification. Even the forensic task is elastic in character. Draft Conclusion 3, for example, suggests that in assessing either practice or opinio juris, "regard must be had to the overall context and the particular circumstances of the evidence in question." It is doubtful that the need to heed context and circumstances (whatever difference may be detected as between them) would escape someone applying Draft Conclusion 3, and at least as likely that the injunction will be taken as delegating a margin of appreciation to any actor applying the principle. Similarly, the conclusions tend almost reflexively toward a non-exclusive, non-hierarchical set of factors with unclear limitations. Draft Conclusion 4, for example, provides that State practice is only "primarily" the focus of inquiry, and the practice of international organizations is relevant in "certain cases," without providing any clues about areas of competence or how one might resolve any conflicts between them.

Each individual topic displays the same tendencies. Draft Conclusion 4(2), as noted, describes the potential significance of international organization practice; although this is explicitly subject to later elaboration in the Special Rapporteur's Third Report, there is little evident interest at this point in limiting this to areas within a given organization's competence. At first blush, the Draft Conclusion suggests that an organization's practice may be germane not only to questions within its purview, but also to questions facing other organizations, and indeed to topics concerning States in State-centered affairs. This may be confirmed or tempered in commentary, undoubtedly, but the Draft Conclusion itself might profitably address this critical issue, including by anticipating concerns about how any organization exceeding the authority given it by States can be said to contribute to State practice.

Likewise, Draft Conclusion 5 (Conduct of the State as State practice) flatly encompasses any State conduct, "whether in the exercise of executive, legislative, judicial or any other functions of the State." Although explored to some degree in Second Report commentary, this poses threshold issues that might be better framed in Draft Conclusion 5 itself. It is surely appropriate to acknowledge that nowadays, State practice is no longer considered limited to heads of State, heads of government, and foreign ministers. Still, one can go overboard. In Draft Conclusion 5, as with international organizations, there is no evident distinction between State institutions evidently competent in international matters — such as the ministry of foreign affairs—and others, like subnational governments, that may be incompetent under national law. Nor is there any attempt 
to suggest, even in the abstract, that the capacity to render practice of evidentiary value will depend considerably on the proposition in question.

The treatment of national court decisions as State practice is illustrative. It seems possible to distinguish circumstances making a claim of State practice stronger or weaker: courts may contribute to the fidelity or internal consistency of State behavior across the board, but they are less likely to be viewed as responsibly taking a lead role in establishing State practice on matters not principally in the judicial domain (questions of civil jurisdiction being different, say, than recognition or the assertion of maritime boundaries). Yet there is not, to this point, any proffered distinction of this kind, consistent with the ILC's longstanding view ${ }^{5}$ that "it is unnecessary to assess the relative the value of national court decisions as compared with other types of evidence of customary international law." By the Second Report's inclusive approach, indeed, we might only hazard that even decisions "that have been reversed on the particular point are no longer likely to be considered as practice"6 (emphasis added). On other occasions national court decisions may be discounted, in words quoted by the Second Report, as too "narrow" or "parochial," but that is more appropriate to their use as subsidiary means of reckoning international law-per Article 38(1)(d) of the ICJ Statute-rather than to their use in establishing State practice. This distinction, too, could be made apparent to consumers of the Draft Conclusions: national courts, and those relying on their decisions, should be alerted to the ease with which their potential roles as expositors and State-related sources can be conflated and simultaneously impaired.

Draft Conclusion 6 (Forms of practice), finally, is entirely consistent with an all-inclusive approach to State practice. Paragraph 2 contains a lengthy list of possible forms by executive, legislative, administrative, and judicial actors. None of the entries seems startling or objectionable. (Although "executive conduct, including operational conduct 'on the ground" might be better described as "executive conduct, including activities.") Conceivably, one may even infer from the density of executive-based examples something about the typical locus of State practice. The key, though, is that paragraph 2's list, however carefully crafted, is emphatically non-exclusive, and paragraph 3 states plainly that " $[\mathrm{t}]$ here is no predetermined hierarchy among the various forms of practice."

Why would anyone object? Or, put more exactly, why should the ILC moderate the approach it has taken to this point - the careful, sober, and judicious allowance for the countless possibilities of practice-in favor of the more difficult and controversial task of agreeing limiting or hierarchical principles, so crystallized that they can feature even in Draft Conclusions? One reason, I think, is simply to provide better advice to less expert actors. The tactic of indicating the fullest range of possibilities in prominent conclusions, tempered in nuanced (and much lengthier, and less easily surveyed) commentary, presupposes that the problem to be cured is inadequate attention to the diversity of State practice-as opposed to their undisciplined use, or inadequate attention to the two elements in reflecting upon such evidence. That supposition is not selfevident. A bird-watcher's guide, by way of counterexample, is not necessarily optimized by listing in bold type all the objects that have ever graced the skies, regardless of climate or population, and confining to finer type an admission that the practical question is usually just whether it is one or another type of sparrow.

A more concrete basis for concern has to do with the result of accumulating State practice. It would be one thing if the inquiry was simply additive. Draft Conclusion 7(1) recognizes, however, that "[a]ccount is to be taken of all available practice of a particular State, which is to be assessed as a whole," and 7(2) that "[w] here the practice of a particular State varies, the weight to be given to that practice may be reduced." This

5 See Int'l Law Comm'n, Ways and Means for Making the Evidence of Customary International Law More Readily Available 367 , UN Doc. A/CN.4/34 (1950), reprinted in [1950] 2 Y.B. INT’L L. CoMm’N 367, UN Doc. A/CN.4/SER.A/1950/Add.I.

6 See Wood, supra note 4, at 24.

${ }^{7} \underline{I d}$. 
is both entirely appropriate and dangerous. For any given State, scrupulously detailing the many forms of State practice might converge on a mean; on the other hand, particularly if relative significance and authority are left unsettled, adding one datum may moot another, if the stars have not aligned, so that more practice amounts to a zero-sum inquiry. Among the community of States, it tends to penalize those in which many actors govern and address matters touching international law, in favor of those States with less democratic or egalitarian structures. The United Kingdom-with its ministers, houses of Parliament, courts of many colours, and (potentially) devolved institutions-will find its contribution to State practice more compromised than will an authoritarian regime that brooks no disagreement, including by a truly independent judiciary.

If these concerns have merit, what can be done? Undoubtedly the ILC will make necessary headway in discussing additional conclusions and refining its commentary, and there will be many allusions to the need to prudently attribute an appropriate amount of weight to various forms. Undoubtedly, too, it is far easier to raise these issues than to resolve them. Three potential solutions may be worth considering.

First, for every indication in a Draft Conclusion that a form of evidence is non-exclusive, the ILC might compensate by doing two things. One would be to strike any forms that are enumerated but remain secondary or incidental, confident that they will be rescued by the omnibus clause and mentioned in the commentary. The Draft Conclusions could also keep pace with matching reminders that the inquiry must remain connected to the ultimate objective: that is, showing a general practice accepted — by that State—as law. However formulated, this would help discipline the tendency of users to populate all available categories by dutifully surveying and counting marginal evidence, even if that evidence is sometimes more of an echo of State practice than a meaningful contribution to it.

Second, State practice should be mustered and assessed in light of the relative competence of State actors. This is difficult, especially for outsiders not acquainted with national laws bearing on the question. Yet it is important to assess-when different State actors are the source of a purported inconsistency-whether one of them is ultimately responsible, both in order to appreciate that State's own understanding of its practice and for fair treatment relative to other States. A minimal safeguard would be to give priority in cases of conflict to the most relevant actors under national and international principles. Thus, for example, Draft Conclusion 7(2) might be altered to state that "[w] here the practice of a particular State varies, such that it is impossible to determine authoritatively, the weight to be given to that State's practice may be reduced."

Third, if the ILC maintains its diverse and non-discriminating approach to State practice, it might require equivalent attention to international organizations as that aspect of its project progresses. Quite likely this seems paradoxical and impossible to square with any focus on States. Still, it may better to ensure that the practice of international organizations, too, will be scrupulously scrubbed for internal consistency and dismissed in the event an organization has blown hot and cold—or ceased, mysteriously, to blow at all.

Despite the focus of these observations, this challenge is not limited to how the principles relating to State practice should operate. Anyone trying to identify the rules for "Identification of customary international law" has to consider how broadly to canvass for evidence of those rules-and the issue of how, if many forms of evidence are considered, one may maintain focus on the most important or most probative. As the ILC moves beyond the basics of State practice and opinio juris to more esoteric topics like specially affected states and persistent objection, it may be forced to search farther and wider for meaningful indicia of how States (and others) have regarded these doctrines, while accepting the possibility that the evidence may be too scanty to support any particular conclusion - at least before any intercession by the ILC itself. Those of us in the field will continue to watch its efforts with interest and admiration. 